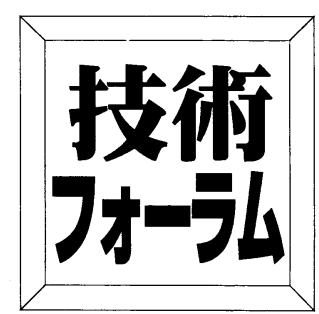

（第 2 回）

\title{
資源の有効利用と 1-1
}

\section{再生骨材を用いたコンクリート}

\section{阿部道彦}

\section{1.はじめに}

前回はコンクリート解体材の再利用状況全般について の紹介 ${ }^{1)}$ がありましたが, 今回はそのうち再生骨材とそ れを用いたコンクリートについて紹介します。

コンクリートは, 骨材をセメントペーストで結び付け たものです。セメントペーストは経年により少しずつ当 初の性能を失うことがありますが，骨材はアルカリ骨材 反応とか軟石のポップアウトといった現象を除けば，多 くの場合ほぼ当初の品質を保持したまま保存されていま す。このような, いわば構造物中に保存された骨材をな ぜ再利用する必要があるのでしょうか。

一つは, 骨材の資源投入量に占める割合です。わが国 では年間 23 億トンもの資源が投入されており，その約 半分が建設資材で, また 4 分の 1 がコンクリート用骨材 で占められています。すなわち，質量で最も多い割合を 占めているのがコンクリート用骨材であり，国民 1 人当 たり年間 5 トンもの量を毎年蓄積していっていることに なります。このように骨材はその使用量が膨大であるた めに，採取に当たり環境に様々な影響を与えてきていま す。そしてこれからは環境への影響をできるだけ少なく する形での骨材供給が要請されています。

二つ目はコンクリート解体材の量の問題です。コンク リート構造物は半永久的な耐久性をもっているといわれ ていますが, 構造物の機能的な寿命により意外と短い期 間で解体されているのが実状のようです。こうして排出 されるコンクリートがら（コンクリート塊）は年々増加 しており, その処分場の確保が次第に困難となっていま す。すなわち，コンクリート塊はその耐久性のゆえに永 久に消失することなく，構造物から処分場の廃棄物に形 をかえて蓄積され続けることになるのです。このため,

* あべ・みちひこ/建設省建築研究所 第二研究部 無機材 料研究室 室長 (正会員)
コンクリート塊の処分の面からも環境に悪影響を及ぼさ ない方策が要請されているのです。

このようにみてくると, コンクリート塊の再利用は資 源の有効利用を図るうえで必然的に出てくる解決策の一 つであることがわかります。そして当面の道路用骨材へ の利用から, 次第にコンクリート用骨材への利用へ進展 していくものと期待されています。

\section{2. 研究の背景と経緯}

コンクリート構造物を解体したあとに排出されるコン クリート塊を再びコンクリート用骨材として使用しよう とする研究は, すでに第 2 次世界大戦直後からソ連やド イツなどで行われていたようです2)。わが国では 1971 年より研究が開始され, 1974 年に建築業協会に委員会 が設置され，本格的に取り組まれることになりました。 また, 1976 年にはコンクリートの解体と再利用に関す る RILEM（スイス民法第 60 条に基づく非営利団体 で，国際材料構造試験機関連合の略称）の技術委員会 37-DRC (Demolition and Reuse of Concrete) が発 足し, その第 1 回の会合が 1977 年英国のガーストンの 建築研究所で開催されましだ)。また, コンクリートの 解体と再利用に関する国際シンポジウムも第 1 回 (1985 年ロッテルダム), 第 2 回 $(1988 \text { 年東京 })^{4)}$, 第 3 回 $(1993 \text { 年デンマーク・オーデンセ })^{5), 6)}$ と開催されてお り，この問題が先進国共通の課題となっていることを示 しています。

上記建築業協会の研究成果 ${ }^{7)}$ は, 1981 年から開始され た建設省の総合技術開発プロジェクト「建設事業への廃 棄物利用技術の開発に関する調查研究」(略称 : 総プロ 「廃棄物」）に取り込まれ，いくつかの基準が作成され ました ${ }^{8), 9)}$ が, 当時はまだ現在ほど廃棄物の問題が逼 迫しておらず，実用化には至りませんでした。この問題 が再び総プロ「建設副産物の発生抑制・再生利用技術の 
開発」(略称：総プロ「副産物」) として取り上げられる に至った背景としては以下のことがあげられます。

(1) 当時の解体コンクリート量は, 正確な統計はあり ませんがそれでも数百万トン程度と推計されていた ${ }^{10)}$ のに対し, 平成 2 年度では 2500 万トンと推計され ${ }^{11)}$, 大都市圈では最終処分場が逼迫してきました。さらに, 解体コンクリート量は今後かなりの期間にわたって増加 する傾向にあると予測されます ${ }^{12)}$ 。

(2) 再生骨材の用途としては現在道路用がほとんどで すが，コンクリート用骨材 (現在約 6 億トン) と道路用 骨材（現在 3 億トン）の量的および地域的需給のバラン スを考えると, 将来とも道路用だけで再生骨材を吸収す ることには無理があります ${ }^{13)}$ 。また, リサイクルの基 本的な考え方からするとコンクリート用に使用されてい たものはできるだけコンクリート用として, あるいは建 築物に使用されていたものは，できるだけ建築物で再使 用することが望ましいと考えられます。

(3) 当時よりコンクリート塊の破砕技術が進歩し, 品 質の良い再生骨材が製造できるようになってきました が，このような再生骨材を用いたコンクリートに関する データが少ない。

(4) コンクリート用骨材は砂利・砂から砕石・砕砂へ 移行しつつあり ${ }^{14)}$, これにともなって $\mathrm{AE}$ 減水用やさ らには高性能 $\mathrm{AE}$ 減水剂が普及しつつありますが，こ れらを再生骨材を用いたコンクリートに適用した場合の データが少ない。

また，総プロに先行して実施された再生骨材を使用し たコンクリートに関するアンケート調查では, 再生骨材 がコンクリート用骨材として使用されない理由の上位と して「品質の安定性に対する不安」と「制度上の問題」 があげられていました ${ }^{15) 。 ~}$

これらのことから，これまでの研究成果をふまえて，

\begin{tabular}{|c|c|}
\hline 揭載号 & テーマ/執筆予定者 \\
\hline 95 年 10 月 & 1. 解体材の再利用 $/$ 河野 \\
\hline \multirow[t]{13}{*}{95 年 12 月 } & 2. 再生骨材の利用/阿部 \\
\hline & 3. 各種廃棄物の利用 $/$ 吉兼 \\
\hline & 4. スラグ骨材の利用 /國府 \\
\hline & 5. 高炉スラグ微粉末の利用／依田 \\
\hline & 6. シリカフュームの利用 $/$ 松藤 \\
\hline & 7. フライアッシュの利用／大賀 \\
\hline & 8. 生コンスラッジの利用 $/$ 畑中+鈴木 \\
\hline & 9. コンクリートの性能評価／田澤 \\
\hline & 10. セメントの製造と資源の利用 $/$ 中野 \\
\hline & 11. 二次製品の製造と資源の利用 /丸山 \\
\hline & 12. 合板型枠の使用の削減／小野 \\
\hline & 13.＼cjkstart構造物を長持ちさせる技術／宮川 \\
\hline & 14. 資源の有効利用の将来 /河野+渡辺 \\
\hline
\end{tabular}

さらにその後の技術の進歩に基づいて再生骨材の利用技 術を開発することはきわめて意義のあることといえま す。建築業協会や総プロ「廃棄物」の成果については既 に紹介されていますので7) 9), ここでは総プロ「副産 物」の成果を中心に, 通常の普通コンクリートを原コン クリートとした再生骨材とそれを用いたコンクリートに ついて紹介したいと思います。

なお, 最近では原子力発電施設の解体材 ${ }^{16)}$ や軽量コ ンクリート ${ }^{17)}$ を原コンクリートとした研究や再生骨材 を高強度コンクリートに使用する試みも行われており， 今後の研究の進展が期待されます。

\section{3. 再生骨材の性質}

\section{(1) 粒子構成}

コンクリート塊を粉砕・分級して製造した再生骨材 は，コンクリート中にもともと入っていた骨材（原骨 材), それにセメントペーストやモルタルの付着したも の, セメントペーストやモルタルだけの粒子に大別され ます (写真 -1$)$ 。

再生粗骨材の場合には，構成粒子の比重・吸水率分布 が調查されており ${ }^{18), 19)}$ ，モルタル粒子の量が再生粗骨 材の品質を左右する要因の一つであることがわかってい ます。すなわち，コンクリート塊を単に砕いて分級した だけの再生粗骨材は原骨材のほかモルタル粒子の割合が 多いのですが, 粉砕あるいは研磨処理を繰り返すと吸水 率の大きいモルタル粒子の割合が減少してくるのがわか ります（図-1）。また，このことから，再生粗骨材の品 質改善には粉砕あるいは研磨といった技術よりも比重選 別の方が効果的であることがわかります。なぜなら，粉 砕はモルタル粒子の除去には効果的ですが原骨材まで砕 いてしまうおそれがあり, 研磨はモルタルの付着した粒 子からモルタルを取るには効果的ですが，モルタル粓子 の除去には効果がないからです。再生粗骨材の比重選別

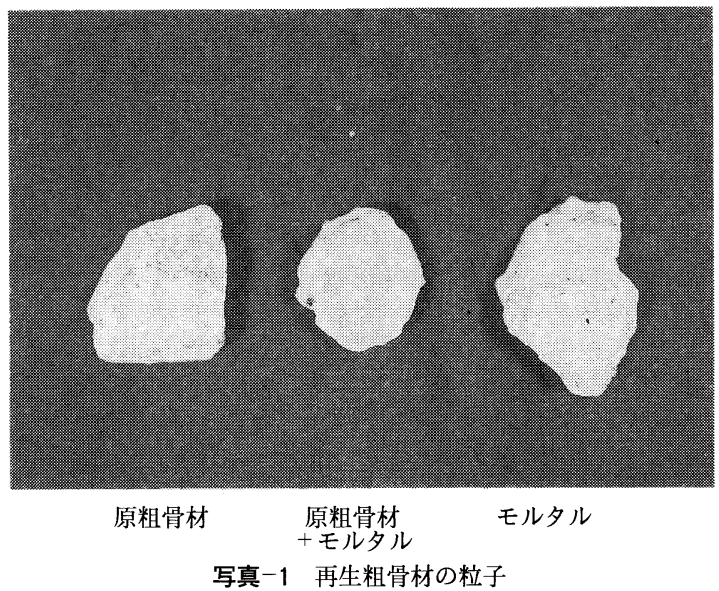


については最近になって技術開発が行われました。

（2）粒子の寸法と品質

再生骨材の粒子の寸法が小さくなるほど再生骨材の品 質は悪くなります。これは, 再生粗骨材の場合にはモル タルの割合が, 再生細骨材の場合にはセメントペースト の割合が多くなるためです。このため，たとえば粗骨材 の比重・吸水率試験は $10 \mathrm{~mm}$ 以上ではなく $5 \mathrm{~mm}$ 以上 の試料について行う必要があります。JISで $10 \mathrm{~mm}$ 以 上としてるのは, 天然骨材の場合, $5 \mathrm{~mm}$ 以上と 10 $\mathrm{mm}$ 以上で害用上問題となる差が生じないためと考え られますが，再生骨材の場合には明瞭な差があるた め20)（図-2)，5 mm 以上で試験をしておかないと,
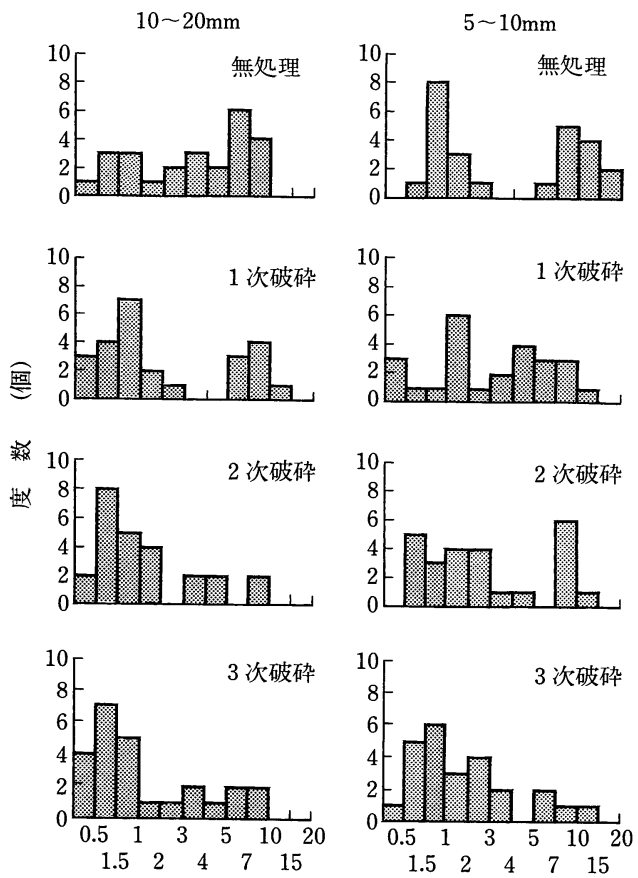

吸水率 $(\%)$

図-1 破砕回数の増加による再生粗骨材粒子の吸水率の変化

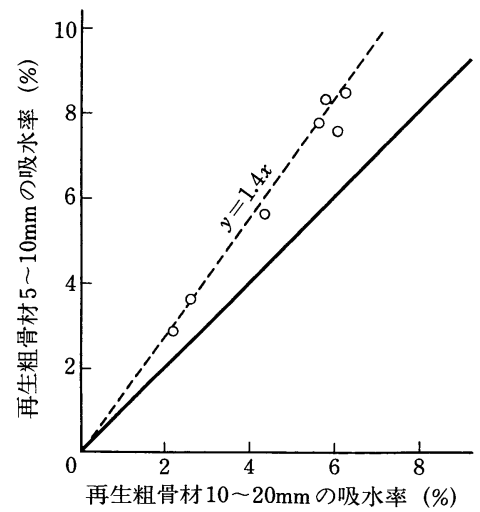

図－2 再生粗骨材の粒径による吸水率の相違
調合をはじめ, 粗骨材の実積率, 質量法による空気量の 算定などに誤差を生じることになります。

(3) 不純物

塗料や仕上材の接着剂などのように解体前も解体後も 除去することが困難なものをはじめ，木・紙・断熱材・ $\mathrm{P}$ タイル・防水用アスファルト等の不純物は再生骨材の 品質に大きく影響するものです。これに対して, ガラス ・石材・タイル・れんがなどは骨材品質にあまり大きな 影響を与えません。また, 鉄筋等の金属材料は再生骨材 の処理工程において, 破砕・分級の障害になることがあ ります 21 。

これまでコンクリート構造物, とりわけ建築物の場合 には, 解体時にコンクリート以外の材料が混入すること が多いといわれていましたが，現在では以前のような一 括解体は減少し, 分別（選別）解体が普及しつつありま す。このため, 不純物の量は質量で $1 \%$ 以下程度に なっています。

\section{（4）再生細骨材の粒度・微粉分}

再生細骨材の粒度分布は一般に下に凸の形を示し，特 に 2.5 5 mm の割合が多くなりがちです。このため通 常の細骨材の粒度分布に近づけようとすると, どうして も 2.5 5 mm の部分をある程度除去しなければならな くなります。

また，再生細骨材には微粉がかなり含まれることにな り, 乾式製法の場合には空気式分級機によりこれを除去 する必要があります。湿式分級の場合には乾式分級より 微粉量を減少させることができるとされておりますが, 水洗後の排水処理の問題が指摘されています。技術的に はシックナーなどを用いることにより解決されています が, 残ったケーキの処理は乾式の場合同様, 今後の課題 といえます。

\section{4. 再生骨材コンクリートの性質}

再生骨材コンクリートの性質は, 再生骨材としてどの ような品質のものを用いるかによって決まります。分別 解体が普及すると, 再生骨材の品質は主としてそれに含 まれるモルタルの量によって決まるといえます。よくコ ンクリートはセメントペーストと骨材の二相材料という 言い方がされますが, 再生骨材コンクリートの場合には

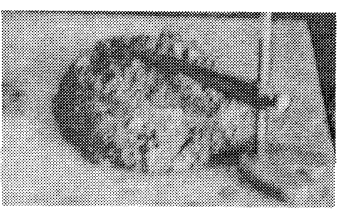

砕 石

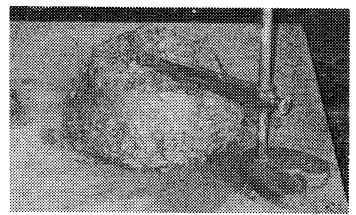

再生粗骨材吸水率 $7 \%$
写真-2 砕石コンクリートと再生骨材コンクリートの ワーカビリティーの比較 
その骨材部分が原骨材と硬化セメントペーストから構成 されているやや複雑な二相材料といえるでしょう。以 下, フレッシュコンクリートと硬化コンクリートの性質 について再生骨材コンクリートの使用方法と関連付けて 述べてみたいと思います。

(1) ワーカビリティーと調合

粗骨材に再生骨材を，細骨材に砂を使用したコンク リートのワーカビリティーを通常の砕石コンクリートと 比較してみますと, 単位粗骨材かさ容積 (単位粗骨材容 積）およびスランプを同一にした場合，再生骨材コンク リートの方がややもったりした感じのコンクリートとな り, 特に水セメント比の大きい領域ではその差が顕著に 感じられます（写真-2）。この理由としては, 再生粗骨 材に含まれる微粉や練混ぜによって再生粗骨材に付着し たモルタルがくずれたり, 再生粗骨材とセメントペース トの付着が良いことなどによるものと考えられます。こ のことは，再生粗骨材を使用した場合には砕石コンク リートより単位粗骨材かさ容積を増加させることができ ることを意味しています。再生骨材コンクリートの単位 粗骨材かさ容積を変化させて目視により砕石コンクリー トと同様のワーカビリティーの得られる調合（配合）を

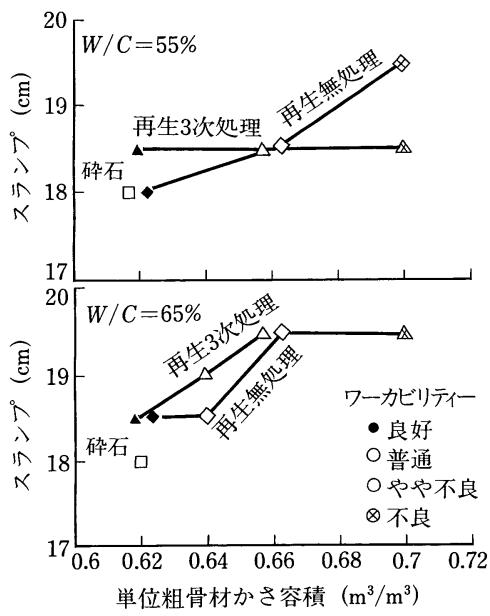

図-3 単位粗骨材かさ容積とスランプの関係

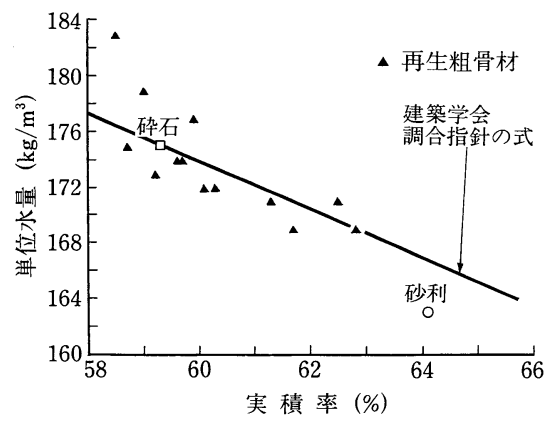

図-4 再生粗骨材の実積率と単位水量の関係
求めたところ, 水セメント比 $55 \%$ の場合には, 単位粗 骨材かさ容積 $0.62 \mathrm{~m}^{3} / \mathrm{m}^{3}$ の砕石コンクリートは単位 粗骨材かさ容積 $0.66 \mathrm{~m}^{3} / \mathrm{m}^{3}$ の再生骨材コンクリート と, また, 水セメント比 $65 \%$ の場合もほぼ同様の対応 があると推測されますので，再生骨材コンクリートは砕 石コンクリートより単位粗骨材かさ容積を $0.04 \mathrm{~m}^{3} / \mathrm{m}^{3}$ まで増加できることがわかりました ${ }^{22)}$ (図一3)。

単位水量については, 砕石の場合と同様, 再生粗骨材 の実積率による補正を行うことによりほぼ推定できると いえます22）（図-4）。すなわち，再生粗骨材の場合も 形状の悪いものすなわち, 処理の程度が低いものは単位 水量が多くなり, 形状がよくなるとすなわち, 処理の程 度の高いものは，単位水量が少なくなるといえます。

(2) ブリーディング

再生骨材コンクリートのブリーディングは砕石コンク リートに比べて少なくなります23)（図一5）。これは再 生粗骨材に含まれる微粉やモル夕ル分の保水性に起因す ると考えられます。これは軟練りコンクリートの場合に は問題ありませんが, 硬練りコンクリートでは逆に表面 仕上げが困難になったりすることもあるので注意が必要 です。

（3）圧縮強度

再生コンクリートの圧縮強度は, 強度の低いレベルで は再生粗骨材の品質が悪くてもあまり影響を受けません が，強度のレベルが高くなってきますと，再生粗骨材の 品質により差が生じ，コンクリート塊を単に砕いただけ

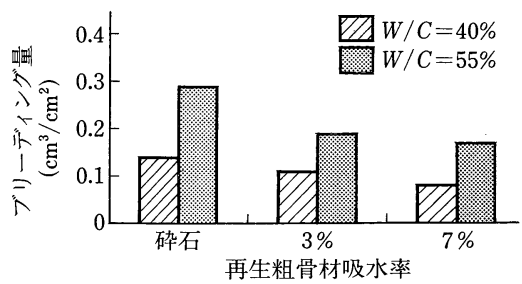

図-5 粗骨材の種類とブリーディング量の関係

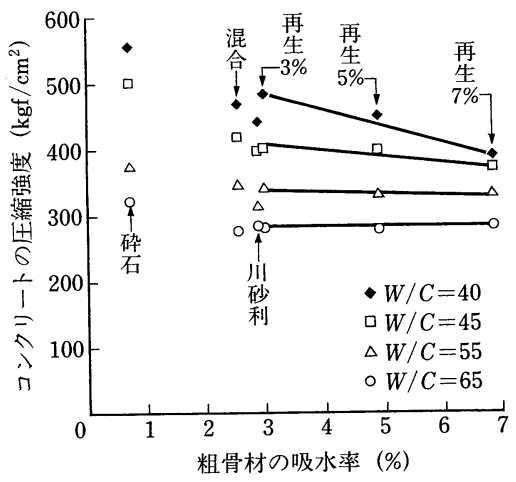

図-6 粗骨材の吸水率と圧縮強度の関係 
のものでは強度の発現が低くなります23）（図一6）。そ れでは, 再生骨材コンクリートはどの程度の設計基準強 度のコンクリートにまで使用できるかということになり ますと，まだ適切な判定方法がありません。このため， 人工軽量骨材について定められている建設省住宅局建築 指導課長調達の方法 ${ }^{24)}$, すなわち水セ义ント比 $40 \%$ の プレーンコンクリートの 4 週圧縮強度によって判定する 方法によると（図-6 の実験は AE コンクリートである ため, 安全側に判定されます), 吸水率 $5 \%$ 以下の再生 粗骨材の場合には, 圧縮強度 $400 \mathrm{kgf} / \mathrm{cm}^{2}$ 以上が得ら れているため設計基準強度 $270 \mathrm{kgf} / \mathrm{cm}^{2}$ に, また, 吸 水率 $7 \%$ の再生粗骨材でも設計基準強度 $240 \mathrm{kgf} / \mathrm{cm}^{2}$ まで使用できることになると判断されます。ただし， JASS 5 などでは, 通常の品質の骨材に対しても設計基 準強度 $240 \mathrm{kgf} / \mathrm{cm}^{2}$ までしか使用を認めていませんの で，当面はこの範囲で使用するのが妥当でしょう。

\section{(4) ヤング係数}

コンクリートを構成しているセメントペーストと骨材 を比較しますと, セメントペーストの方がヤング係数は 小さくなっています。このため, 再生粗骨材に含まれる モルタル分が多くなるほどコンクリート全体としてのセ メントペーストの量は多くなり, ヤング係数は小さくな ることになります。これは部材としてのたわみやクリー プの増大だけでなく, 後述する乾燥収縮の増大の原因と もなります。コンクリートの比重と圧縮強度およびャン グ係数により日本建築学会のヤング係数算定式における 係数を逆算で求めてみると, 再生粗骨材の吸水率が 5

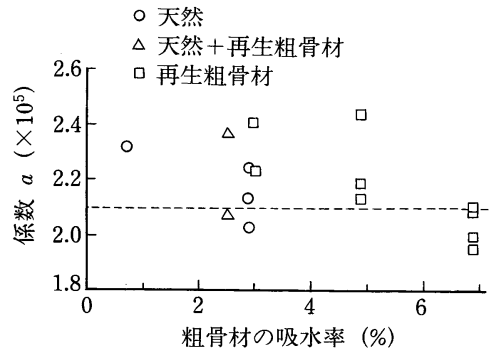

図-7 粗骨材の吸水率とヤング係数評価式の係数 a の関係

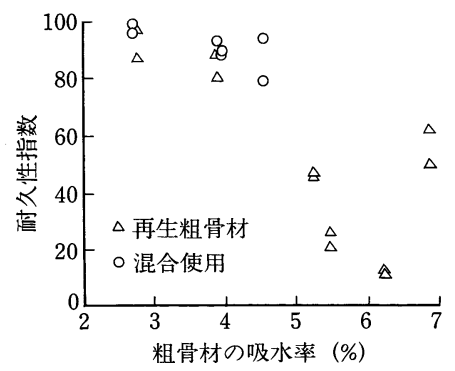

図-8 粗骨材の吸水率と耐久性指数の関係
\%を超えると現行の係数 $2.1 \times 10^{5}$ を下回ることになり ます25)（図一7）。

\section{(5) 凍結融解抵抗性}

通常のコンクリートの凍結融解抵抗性は空気量によっ て左右されますが，十分な量の空気が連行されていても 骨材の品質が悪いと凍結融解抵抗性が劣ることがありま す。このため, 砂利では吸水率 $3 \%$ 以下, 砕石ではこ のほか安定性 $12 \%$ 以下との規定があります。

再生骨材コンクリートは, 再生粗骨材に含まれるモル タル分が多いと凍結融解に対して悪影響を及ぼします。 ただし, 吸水率で $5 \%$ 以上になると凍結融解抵抗性は 急激に悪くなりますが，これ以下では比較的良好な状態 になっています 26 ）（図-8）。このため再生粗骨材の場 合には, 通常の骨材よりやや吸水率を多くできる可能性 があるといえます。

（6）乾燥収縮

セメントペーストの乾燥収縮に対して骨材は抵抗しま す。再生粗骨材に含まれるモルタルは通常の骨材に比べ てヤング係数が低いためセメントペーストの乾燥収縮に 対する抵抗が弱く，したがって再生骨材コンクリートの 乾燥収縮は通常のコンクリートに比べてやや大きくなり ます。吸水率 $1 \%$ の砕石を用いたコンクリート，吸水

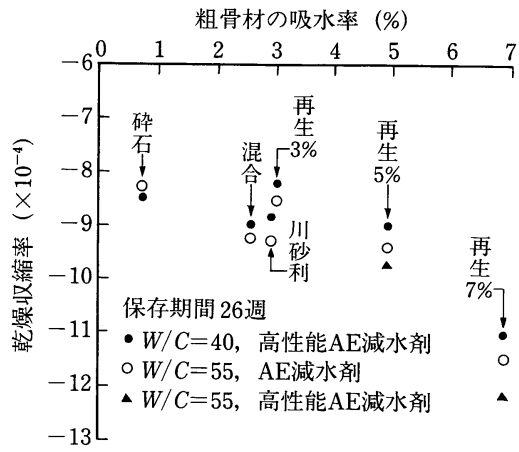

図-9 粗骨材の吸水率と乾燥収縮率の関係

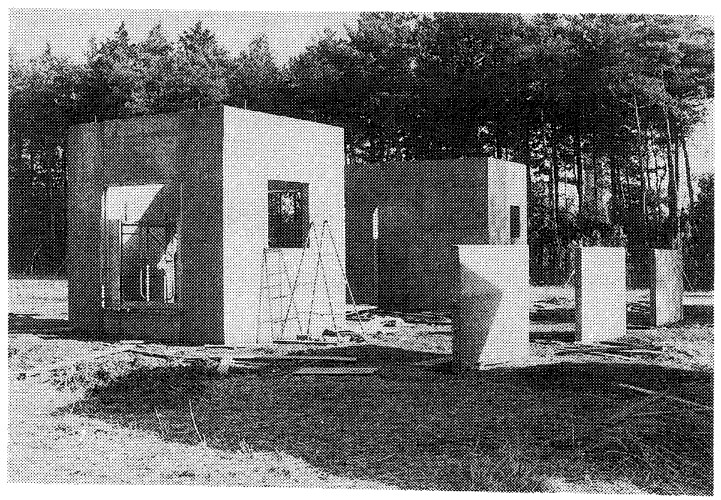

写真-3＼cjkstart再生コンクリートで作製した壁体 
率 $3 \%$ の砂利を用いたコンクリートと再生骨材コンク リートの乾燥収縮を比較した結果では, 再生粗骨材の吸 水率が $7 \%$ の場合には, 乾燥収縮はかなり大きくなり ましたが, $5 \%$ の場合には砂利コンクリートとほぼ等し い值を示しています ${ }^{23}$ （図-9）。また，この実験では 乾燥收縮を小さくするため, 通常使用される混和剤であ る $\mathrm{AE}$ 減水剤のほかに高性能 $\mathrm{AE}$ 減水剤を使用した場 合も検討しましたが, 明確な効果は認められませんでし た。このため, 乾燥を受けるところに再生骨材コンク リートを使用する場合には, 使用する再生骨材の品質や 収縮低減のための対策を検討する必要があるといえま す。

（７）暴露による品質変化

総プロ「廃棄物」のときに作製した壁体（写真-3） の材齢 10 年における品質試験結果 ${ }^{27)}$ によりますと, 中 性化も普通コンクリートと同程度で，また壁面にはひび 割れもほとんど認められませんでした。ただし，コアの 圧縮強度は材齢 3 か月より増加していましたが，ヤング 係数にはやや低下を示す場合があり，今後の品質変化が 注目されます。

\section{5. 再生骨材コンクリートの利用上の 問題点}

上述した再生骨材コンクリートの実験結果から考える と, 再生骨材コンクリートの利用の方向として, 再生骨 材の処理の程度を高めることにより普通コンクリートに できるだけ近づけるという方向と再生骨材コンクリート の特性に応じて使用部位を限定するという方向が考えら れます ${ }^{28)}$ 。前者の場合には現行の生コンプラントによ る製造システムに比較的容易にのせることができます が, 後者の場合には現行のシステムの中で実際に再生コ ンクリートを製造し施工することが可能なのか，あるい は別のシステムをつくる必要があるのか検討すべき点は 多いと思われます。前者にしても再生骨材の JIS 化と いう手続き，あるいは JIS 相当品としての認知が必要 となるでしょう。

経済性という面から考えると, 輸送費の点で再生骨材 の製造工場と再生骨材を使用したコンクリートの製造工 場は隣接していることが望ましいといえます。また，建 替現場で再生骨材とそれを用いたコンクリートの両方を 製造しようとすることも技術的には可能と思われます が, 再生骨材の眝蔵方法, 現場に設置できるコンパクト なコンクリート製造プラント, 再生骨材および再生骨材 コンクリートの品質管理などについて検討が必要と思わ れます。

\section{6. 品質基準の作成と再生骨材の利用の} 動向

建設省大臣官房技術調査室は平成 6 年 4 月に主として 土木分野を対象として再生骨材の用途別暫定品質基準

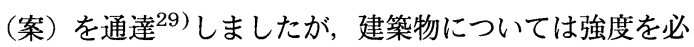
要としない非構造体に限定されています。このため, 現 在上記の研究結果を踏まえて軀体への適用を考慮した品 質基準が検討されています 30 )。

土木の分野では, パイロット事業を通じて再生骨材の 利用が促進されており, 再生骨材を使用したコンクリー 卜二次製品などはかなり積極的に利用されています。

建築の分野では, 中止にはなりましたが, 東京フロン ティア協会主催の世界都市博覧会では細・粗骨材とも全 量再生骨材を使用したコンクリートをパビリオンの基礎 ・地中ばり等へ利用するための工事仕様書が作成されま した ${ }^{31)}$ 。住宅・都市整備公団では, 団地の建替えの際 の再利用について実績を重ねており, 再生骨材を使用し たプレパックドコンクリートの擢壁についても実験的検 討が進められました ${ }^{32)}$ 。このほか，ゼネコンや建築家 による取組みも試みられていますし ${ }^{33)}$ ，住宅基礎への 利用例などもあり, 今後の利用促進が期待されるところ です。

\section{7.おわりに}

以上, 主として総プロ「副産物」の成果を中心に再生 骨材とそれを用いたコンクリートについて述べました。 再生骨材のコンクリートへの利用を考えた場合には, ま だ検討しなければならない課題はいくつかありますが, コンクリート塊は将来確実に増加するものであり, その 有効利用なくして今後の建設活動は語れないともいえる でしょう。

本稿が皆様方にとって再生骨材の利用促進の手助けに なれば幸いです。

執筆にあたり資料を引用させていただきました方々に 感謝いたします。

\footnotetext{
<参考文献・資料 >

1）河野広隆：コンクリート解体材の現状と可能性, コンク リート工学, Vol. 33, No. 10, pp. 91 96, 1995. 10

2) Alan D. Buck（和泉意登志 抄訳）：骨材資源として のコンクリート再生骨材，コンクリート工学, Vol. 16, No. 4, pp. 43 44, 1978. 4

3）社建築研究振興協会 : コンクリートの解体と再利用に関 する第 2 回 RILEM 国際シンポジウム最終報告書, p. $11,1989.6$

4）藤井忠義・菊地雅史：コンクリートの解体と再利用に関 する第 2 回 RILEM 国際会議，セメント・コンクリー ト, No. 504 , pp. 49 56, 1989. 2

5）柳 啓：コンクリートと組積造の解体と再利用に関す
} 
る第 3 回 RILEM 国際シンポジウムに出席して, コン クリート工学, Vol. 32, No. 2, pp. 68〜 70, 1994. 2

6）笠井芳夫 : ヨーロッパにおけるコンクリートの解体と再 利用を見て, セメント・コンクリート, No. 566, pp. $9 \sim 15,1994.4$

7）时建築業協会建設廃棄物処理再利用委員会 : 再生骨材お よび再生コンクリートの使用規準（案），コンクリート 工学, Vol. 16, No. 7, pp. 42 46, 1978. 7

8）樫野紀元：廃棄物の建築用コンクリートへの再利用，コ ンクリート工学, Vol. 25, No. 5, pp. 17〜27, 1987. 5

9）河野広隆：「再生骨材を用いたコンクリートの設計・施 工指針（案)」について, 土木施工, 27 巻 15 号, pp. $110 \sim 113,1986.11$ 臨

10）笠井芳夫 : 再生骨材の使用規準，セメント・コンクリー ト, No. 415 , pp. $182 \sim 188,1981.9$

11）建設省土木研究所 : 建設副産物の発生及び処理・処分の 実態に関する調査報告書, p. 15, 1992.4（建設省建設 経済局「建設副産物実態調查」)／または前川秀和：建設 省における建設副産物の資源化対策, 土木学会誌, pp. 42〜 45, 1992. 6/あるいは奥平 聖 : コンクリート塊と リサイクル, セメント・コンクリート, No. 550, pp. $1 \sim 8,1992.12$

12）高橋泰一 : 建築系副産物の発生抑制之再生利用に関する 問題点, 日本建築学会大会学術講演梗概集, pp. 377〜 378，1994.9/または財国土開発技術研究センター：再 生コンクリート利用技術の開発 平成 5 年度報告書, p. 104，1994.3/あるいは高橋泰一: 建設副産物発生量の 現状と長期予測, あらか第 12 集, 建設省建築研究所, pp. 59〜70, 1994. 11

13）佐久田昌治 : コンクリートがらの路盤材への適用の限界 とコンクリートがら高度処理のニーズについて，(盺国土 開発技術研究センター, 再生コンクリート利用技術の開 発 平成 5 年度報告書, pp. 239 241, 1994. 3

14）日本建築学会材料施工委員会骨材小委員会実態調查WG : コンクリート用骨材に関する全国調查結果，セメント ・コンクリート, No. 529, pp. 20〜33, 1991. 3

15）(㮩国土開発技術研究センター：再生コンクリート利用技 術の開発報告書, pp. 25 46, 1992. 3

16) 出口 朗・藤原啓司・鈴木一弘・神山行男 - 山本雄一 : 解体コンクリートの再生骨材としての再利用 (その 1), 日本原子力学会「1993 年春の年会」予稿集 B 42

17）菊地雅史・道正泰弘・安永 亮・江原恭二・増田 彰 : 再生骨材の品質が再生コンクリートの品質に及ぼす影 響, 日本建築学会構造系論文集, 第 474 号, pp. 11〜 20, 1995. 8

18）阿部道彦: 総プロにおける再生骨材利用技術の開発状 況, あらか第 12 集, 建設省建築研究所, pp. 79〜86, 1994. 11

19）崔 敏壽・南波篤志・阿部道彦・金武漢 : 建築系副産物 の発生抑制之再生利用に関する研究 (その 4 . 再生骨材 の粒子構成), 日本建築学会大会学術講演梗概集 $A-1$, pp. 853〜854, 1995.8

20）(財国土開発技術研究センター：再生コンクリートの利用 技術の開発 平成 6 年度報告書, p. 467, 1995. 3

21）石塚冬樹・佐久田昌治 : 建築系副産物の発生抑制之再生 利用に関する研究 (その 3 . 解体工事における副産物発 生抑制技術), 日本建築学会大会学術講演梗概集 $\mathrm{A}-1$, pp. 851 852, 1995. 8

22）南波篤志・阿部道彦：建築系副産物の発生抑制と再生利 用に関する研究 (その 6.再生コンクリートの調合の方 法), 日本建築学会大会学術講演梗概集 A-1, pp. 857 $858,1995.8$

23）南波篤志・阿部道彦・棚野博之・前田弘美 : 再生コンク リートの品質改善に関する実験，コンクリート工学年次 論文報告集, Vol. 17, No. 2, pp. 65 70, 1995. 6

24）建設省住指発第 32 号, 人工軽量骨材を用いる軽量コン クリートの使用基準および性能判定基準について, 1991. 1. 31

25）剘国土開発技術研究センター : 再生コンクリートの利用 技術の開発 平成 6 年度報告書, p. 439, 1995. 3

26）桂 修・吉野利幸・関口岳彦・鎌田英治 : 再生コンク リートの凍害・初期凍害に関する研究（その 3 . 耐凍害 性之骨材の物性), 日本建築学会大会学術講演梗概集 A-1, pp. 1129 1130, 1995. 8

27）加賀秀治・樫野紀元・阿部道彦・南波篤志 : 建築系副産 物の発生抑制之再生利用に関する研究 (その 7. 再生コ ンクリート壁体の耐久性調查), 日本建築学会大会学術 講演梗概集 A-1, pp. 859〜860, 1995. 8

28）高橋泰一・阿部道彦：再生骨材のコンクリートへの適用 の現状と将来, コンクリート工学, Vol. 33, No. 2, pp. $20 \sim 29,1995.2$

29）建設省技調発第 88 号，建設大臣官房技術調查室長通達 「コンクリート副産物の再利用に関する用途別暫定品質 基準（案)」, 1994. 4.11／または河野広隆 : コンクリー 卜副産物の再利用促進にむけて, セメント・コンクリー ト, No. 572, pp. 52〜 55, 1994. 10/あるいは, 河野広 隆 : 再生材の品質基準（案）の制定について, 月刊生コ ンクリート, Vol. 13, No. 11, pp. 25〜30

30）阿部道彦・桝田佳寛・加賀秀治 : 建築系副産物の発生抑 制と再生利用に関する研究（その 8 . 再生骨材の品質基 準策定の考え方), 日本建築学会大会学術講演梗概集 A-1, pp. 859 860, 1995. 8

31）过順・妹尾高行：世界都市博覧会一東京フロンティ ア一における再生コンクリートの使用の試みについて, 月刊生コンクリート, Vol. 13 No. 11, pp. 54〜 56, 1994. 11

32）香川明人：住宅団地におけるコンクリート廃材のリサイ クル一団地内リサイクルの試み一, コンクリート工学, Vol. 32, No. 4, pp. 5 14, 1994. 4

33）再生 建築軀体への利用を模索 微粉末の処理が課題, 日経アーキテクチュア, pp. 131〜133, 1994. 6. 20 